\title{
Mobile Augmented Reality for Enjoyable Informal Learning in Cultural Heritage Site
}

\author{
Ulka Chandini Pendit \\ School of Multimedia \\ Technology \& Communication \\ Universiti Utara Malaysia
}

\author{
Syamsul Bahrin Zaibon \\ School of Multimedia \\ Technology \& Communication \\ Universiti Utara Malaysia
}

\author{
Juliana Aida Abu Bakar \\ School of Multimedia \\ Technology \& Communication \\ Universiti Utara Malaysia
}

\begin{abstract}
Learning experience at cultural heritage site is highly necessary needed to visitor when visiting cultural heritage sites. However, it is not adequately provided with the existing of traditional media. Augmented Reality is an alternative of the current emerging technologies to be applied at cultural heritage sites to facilitate learning experience. This article presents the design and development of the mobile augmented reality application towards enjoyable informal learning at cultural heritage sites. The application is designed by adapting three major theories, enjoyment theory, mindfulness theory, and design of enjoyable technology. It is expected that the application is able to help visitor learn informally in enjoyable way at cultural heritage site. Finally, the mobile augmented reality application for cultural heritage site towards enjoyable informal learning becomes the main finding of the study.
\end{abstract}

\section{General Terms}

Augmented Reality, Informal Learning

\section{Keywords}

Mobile augmented reality, cultural heritage, enjoyable, informal learning, development

\section{INTRODUCTION}

Augmented reality (AR) is a current emerging technology nowadays. Its breakthrough has made many changes in various fields in terms of technological aspect. AR technology overlays the virtual object into the real world that enables user to have the virtual and real world experience at the same time. AR prefers to add certain virtual object to the real world rather than completely replacing the whole environment [1]. Hence, AR is able to enhance visitor's perception without distracting user from the real world [2]. Mobile AR is a new emerging technology in the market. It attracts the leading brands with $\$ 1.5$ billion revenue stream by 2015 [3]. Since 1997, Mobile AR has developed rapidly in many fields, such as, cultural heritage, education, entertainment, construction, tourism, architecture, marketing, navigation and path finding and geographical field work [4].

Cultural heritage site is the identity of nation that needs to be conserved. Cultural heritage is also a place for learning. Visitors can learn about the history that is hidden under the magnificent architecture of cultural heritage building. This type of learning is called informal learning, where learning is not constrained as an activity that takes place in institutional education but it can be conducted outside the formal institution, in this context, cultural heritage. Consequently, it makes learning process in cultural heritage relies heavily on intrinsic motivation that makes the learning process should be enjoyable [5]. It has impact on visitor for enjoying their visit and does not feel the learning process whereas they obtain the new knowledge at the same time. Informal learning can happen anywhere, in every day's life which relates to work or family. It is also possible for visitors to learn from artefacts, historical places and events. However, the interpretive media that is provided in the cultural heritage does not support the informal learning. Based on the study done by [6], only $8 \%$ of heritage site in Central and East Java, Indonesia that provide digital media (audio and video) as the non-personal interpretive media. Mostly, the interpretive media are in traditional form, such as interpretive boards, booklets and maps, which are not interesting and motivating for visitors [7].

This study implements mobile AR for helping visitor conducting enjoyable informal learning at the cultural heritage site. In order to achieve the result, AR@Prambanan was developed to help visitor to conduct enjoyable informal learning at Prambanan Temple Complex, Yogyakarta. This paper consists of five sections. The second section explains about mobile AR. The third section discuses about the enjoyable informal learning. The fourth section details out the development process of AR@Prambanan application. Lastly, the fifth section is the conclusion of the study.

\section{MOBILE AUGMENTED REALITY}

AR enables user to have the virtual world and the real world in the same time and same space. It augments the virtual object to the real world, such as augments virtual image or textual annotations on the scene [8]. According to [1], AR is defined by three criteria, (a) combines real and virtual, (b) interactive in real time and (c) registered in 3D. AR helps user to perform their tasks by overlaying the virtual object that contains information that helps user to accomplish the task.

Mobile AR applies to the concept of truly mobile, where the system is away from conditioned environments, such as, research laboratories and special work areas [9]. Mobile AR allows user to have AR experience anytime and anywhere. Mobile AR system has specific requirements, which are, wearable input (camera), interaction devices, display, wireless networking, data storage and access, and computational platform [9] [10]. The current increase usage of mobile phone also makes AR is possible to be implemented in mobile phone, beside smart-phone and also tablet [10].

The next section explains about enjoyable informal learning that includes three theories, enjoyment theory, mindfulness theory and design of enjoyable technology. 


\section{ENJOYABLE INFORMAL LEARNING}

As what have been mentioned in introduction, learning in cultural heritage site should be enjoyable. The enjoyable informal learning criteria can be formalized from the three theories, which are enjoyment definition, mindfulness theory and design of enjoyable technology. The mindfulness theory is chosen as the most suitable theory for informal learning in cultural heritage. The enjoyment and design of enjoyable technology relate with the enjoyable and technology element. The followings are the explanation of the three theories:

\subsection{Enjoyment}

According to [5], enjoyment involves three dimensions: (i) engagement, a person should engage and focus in activity with high levels of attention, (ii) positive effect, a person feels good feeling that is aroused from satisfaction, happiness or similar emotions, (iii) fulfilment, a person feels to be fulfilled by doing some activity that makes them achieve their needs. Davis, a psychologist, comes with a theory of enjoyment that $\mathrm{X}$ is enjoying $\mathrm{Y}$ iff $\mathrm{Y}$ is causing $\mathrm{X}$ to have an additive amount of pleasure of what $X$ is experiencing [11]. Warner (1951) has another formula:

A (a person enjoys experience); B (activity); C (concept); $\mathrm{t}$ (time)

\section{(1) A Bs at t'}

(2) A's Bing causes A at t: (i) to believe, of his Bing, that the concepts in $\mathrm{C}$ apply to it, (ii) to desire, of his Bing, under the concepts in $\mathrm{C}$ that it occur;

(3) A desires for its own sake what (2, ii) describes him as desiring [12]

It can be concluded that Warner's definition of enjoyment is an activity that contains pleasure and fulfils desire in certain amount of time. Whereas, Beck said that enjoyment is not a joyful feeling but it is the effect of satisfaction of needs or natural impulse that human experiences [13]. Enjoyment also occurs in a physical activity that makes Dishman states that it is a proximal and tangible influence of behavior that provides an immediate reward as being active in physical [14].

It can be concluded that enjoyable informal learning is a learning process where learner does not feel the "learn" part but at the same time achieving the new knowledge.

\subsection{Mindfulness}

Mindfulness theory is related with mindfulness and mindlessness characters of visitors at cultural heritage site. According to [15], mindfulness and mindlessness have different meaning. Mindfulness means care to the world around us and mindlessness refers to when the person does not active to process new information. Figure 1 depicts two combination factors deals with the interpretative communication at heritage, "communication" and "visitor" factors [16]. The process starts with: each positive element in communication factor influences the visitor factor (high level of fatigue and interest in content), and then goes to the cognitive state (mindful), at the end, visitor accepts the result (more learning, high satisfaction and greater understanding). This will have the opposite result for the process which has lack of communication factor. The mindfulness model can be applied to different situations and organization aims. It is also proved how to get the mindful and mindfulness visitors at heritage site. In summary, the role of communication factor is extremely important.

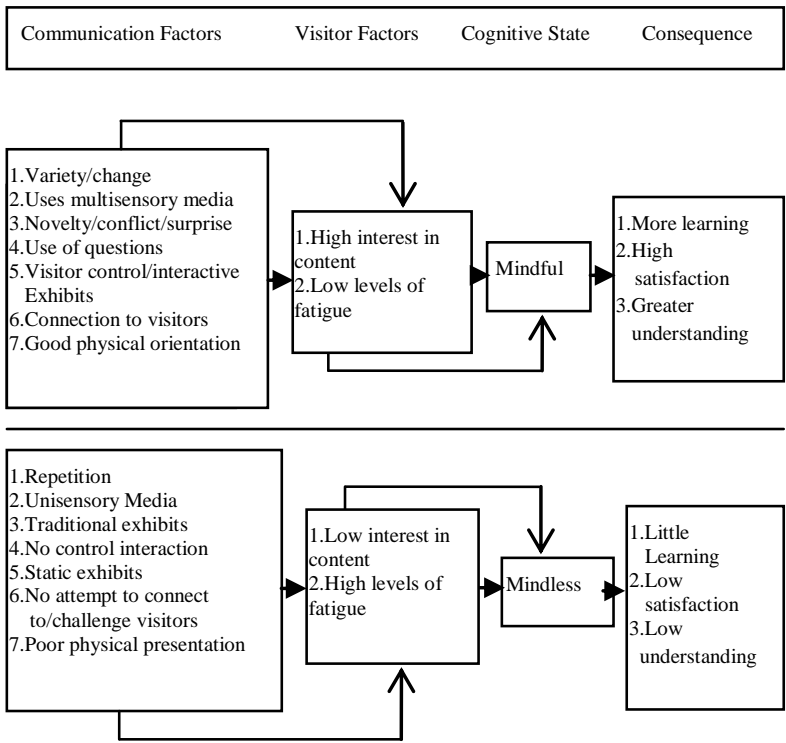

Fig 1: Mindfulness for Communication with Visitors (Moscardo, 1996)

The followings are the explanation of communication factors for mindful character:

\section{a) The Variety / Change}

It is found out that the multisensory, audio visual and dynamic interpretive techniques are good to enhance visitor attention and learning [16]. It is written clearly that the traditional exhibit is one the factors to induce the mindlessness. So it is confirm that in order to create a mindful visitor, the novel and multisensory media are needed.

b) Use of questions

Questions are good to increase visitor's learning. It is one of the cognitive orientation devices for mindful visitors to recall the knowledge that they have got while wandering at the site. Further, guided tours, pre-visit instruction and organization of exhibit material are other types of these cognitive orientation devices.

c) Visitor control / Interactive exhibits

Interactive material is useful to catch and keep visitor's attention as well as to improve their learning and interest [17]. Moreover, by giving the chance for visitors to control the information that they receive will also increase the level of interpretation.

d) Connection with the visitors

An effective interpretation is the one which can relate the present experience with the prior experience of visitors in the past. Since the interest of visitors will not always remain constant throughout their visit so it will be better to connect the heritage story with visitor's story. 


\section{e) Good physical orientation}

Visitors who are easily to find their way inside built heritage are more mindful than those who do not. The presence of maps and signs are highly needed for the visitors. Since mostly visitors prefer to carry the map and ask the way to the staff [17] at the site.

f) Repetition

Repetition of the exhibits is not effective for interpretation as it has potentiality to induce the mindfulness.

\section{g) Novelty / conflict / surprise}

The surprise, conflict or novelty factor is important to keep the interest of visitors and wake them up from the boredom and tiring.

The communication factors for mindfulness character are the contradiction of the ones in mindful character. These factors are the indicator of why visitors can be mindfulness at heritage site.

\subsection{Design of Enjoyable Technology}

The design of enjoyable technology is concluded by [18] as follows:

\section{a. User control and participation}

A set of challenges and activities should be embedded in the technology for users to feel enjoy. The activities should allow users to test their skills also makes users have the feel of control while doing the activities. Then, they can see the effect of their actions as a sense of personal power. The key point of enjoyable experience is the active participation that is given to users.

\section{b. Variation and multiple opportunities}

The opportunities to change or customize the product should be given to user. The set of setting that enable user to personalize the product gives user the feeling of control. These changes are chosen under series of options and variations.

\section{c. Social opportunities and social cohesion}

Technology should allow user to do things collectively in group of people. It should bring user to the cohesion of society where user can interact and feels as part of the group.

All the theories above are the basis guideline in order to find the criteria of enjoyable informal learning. The explanation about the development of AR@Prambanan that includes the criteria and technique are provided in section four.

\section{DEVELOPMENT OF AR@PRAMBANAN: AUGMENTED REALITY APPLICATION AT PRAMBANAN TEMPLE COMPLEX}

AR@Prambanan is developed to help visitors have informal leaning at cultural heritage site. AR@Prambanan application gives the information provision and enhances the visiting experience at Prambanan Temple Complex, Yogyakarta, Indonesia. It assists visitors' understanding and tells the Prambanan Temple history via an engaging and interactive mobile application.

The criteria of AR@Prambanan is taken from the enjoyable informal learning theories, which are, enjoyment, mindfulness and design of enjoyable technology theory (refer to figure 2).

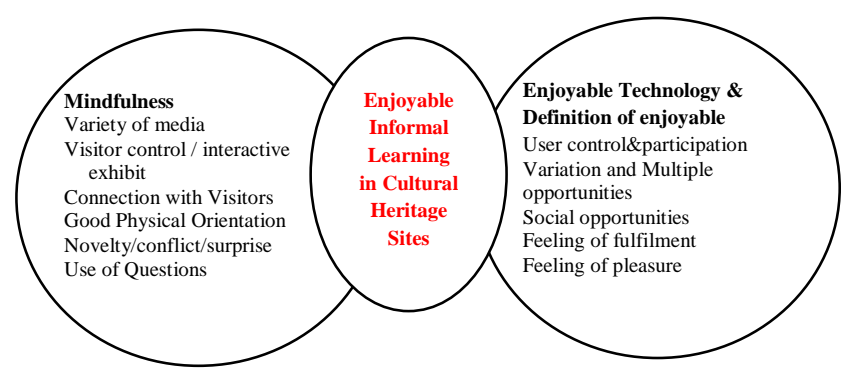

Fig 2. Enjoyable informal learning in cultural heritage site

Below is the link between the criteria and the features in AR@Prambanan application (refer to table 1):

Table 1: Criteria of mobile $A R$ for cultural heritage site towards enjoyable informal learning

\begin{tabular}{l|l}
\hline Criteria & $\begin{array}{l}\text { Mobile AR for Cultural } \\
\text { Heritage Sites towards } \\
\text { Enjoyable Informal Learning: } \\
\text { AR@Prambanan }\end{array}$ \\
\hline Variety of media & $\begin{array}{l}\text { Use variety of media to be } \\
\text { embedded in the application, } \\
\text { such as, text, image, video and } \\
\text { website. }\end{array}$ \\
\hline $\begin{array}{l}\text { User control/visitor } \\
\text { control/interactive }\end{array}$ & $\begin{array}{l}\text { Let user to control their action } \\
\text { towards the application. }\end{array}$ \\
\hline $\begin{array}{l}\text { Good physical } \\
\text { orientation }\end{array}$ & $\begin{array}{l}\text { Use maps to guide users for } \\
\text { finding the location of the } \\
\text { cultural heritage site. }\end{array}$ \\
\hline $\begin{array}{l}\text { Use of questions and } \\
\text { participation }\end{array}$ & $\begin{array}{l}\text { Provide questions about related } \\
\text { cultural heritage site to recall } \\
\text { visitor's learning. }\end{array}$ \\
\hline Novelty/conflict/surprise & $\begin{array}{l}\text { Provide pop up balloons of AR } \\
\text { location of cultural heritage sites } \\
\text { that has background of real } \\
\text { environment. }\end{array}$ \\
\hline $\begin{array}{l}\text { Variation and multiple } \\
\text { opportunities }\end{array}$ & $\begin{array}{l}\text { Provide the options for user to } \\
\text { change the view of application } \\
\text { with live, map and list view. }\end{array}$ \\
\hline $\begin{array}{l}\text { Social } \\
\text { opportunities/social } \\
\text { cohesion }\end{array}$ & $\begin{array}{l}\text { Let users to interact and discuss } \\
\text { about the content of application } \\
\text { with their group }\end{array}$ \\
\hline Feeling of fulfillment & $\begin{array}{l}\text { User feels fulfilled to use the } \\
\text { application for learning n } \\
\text { cultural heritage site }\end{array}$ \\
\hline $\begin{array}{l}\text { User feels happy to use the } \\
\text { application for learning in } \\
\text { cultural heritage site }\end{array}$ \\
\hline
\end{tabular}

Due to technical limitation, the criteria of connection with visitor has not been applied yet in the application.

After obtaining the criteria of enjoyable informal learning, the application is start to be developed. AR@Prambanan is developed using Junaio. Junaio is a freely available for download for mobile users in Android or iOS platforms. The application was developed for one month. The first step is, register an account on http://dev.junaio.com/ (refer to figure 3). Secondly, create a channel for the application. This 
channel contains about information of AR@Prambanan channel (refer to figure 4).

After create the channel, it is continued by creating a webhost for storing all contents for the channel. ] All content, such as, text, video, link of website and quiz will be uploaded to the webhost database (refer to figure 5) that will be connected with Junaio website. The application uses XML file as the markup language, JPEG and PNG as the format for image content, and MP4 for video.
Finally, after all content and coding are uploaded, the development process is done. The application is ready to be used. Figure 6 until Figure 8 are the screen shots of AR@Prambanan application.

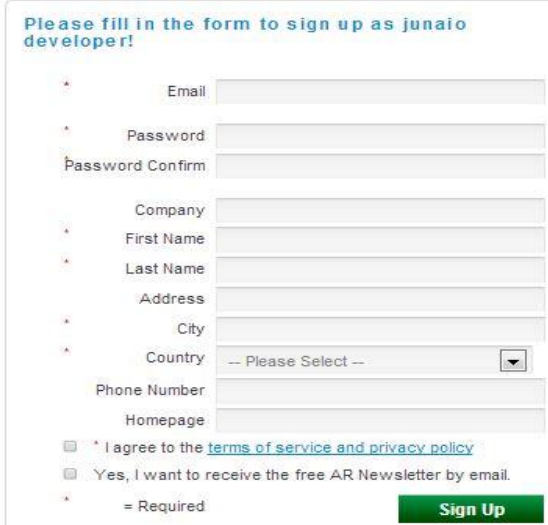

Sign up ! Login to get full access to these

- Get free access to the powerful junaio developer AP

- Create your own Augmented Reality Experience or even App

- Manage your content and application licensing with our metai

Directly upload and manage your content with metaio Creato

Join more than 50.000 AR professionals

Fig 3: Developer's account registration

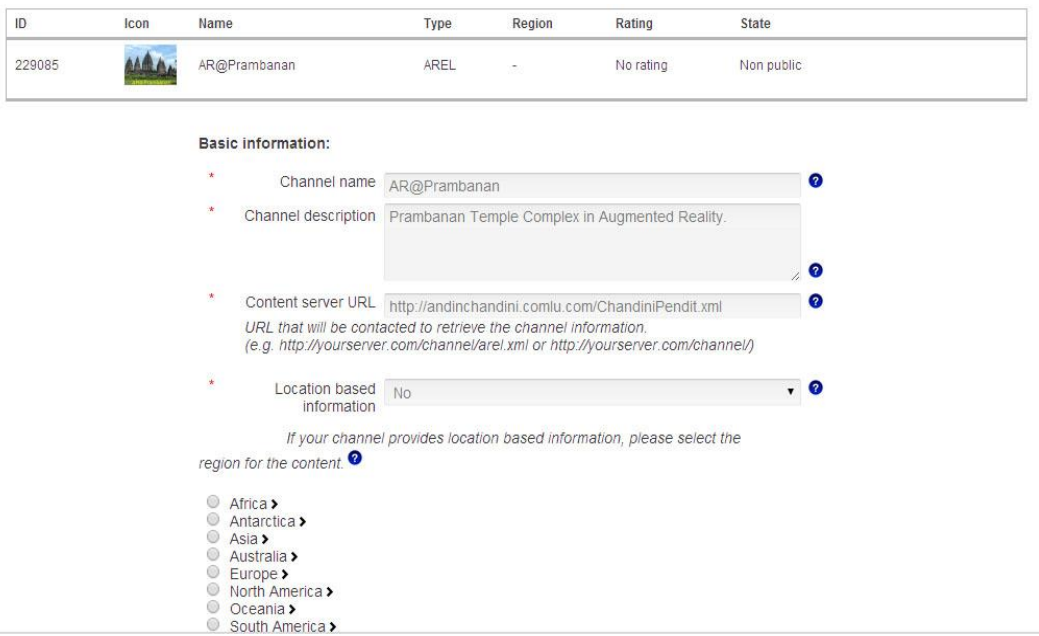

Fig 4: Create AR@Prambanan channel 


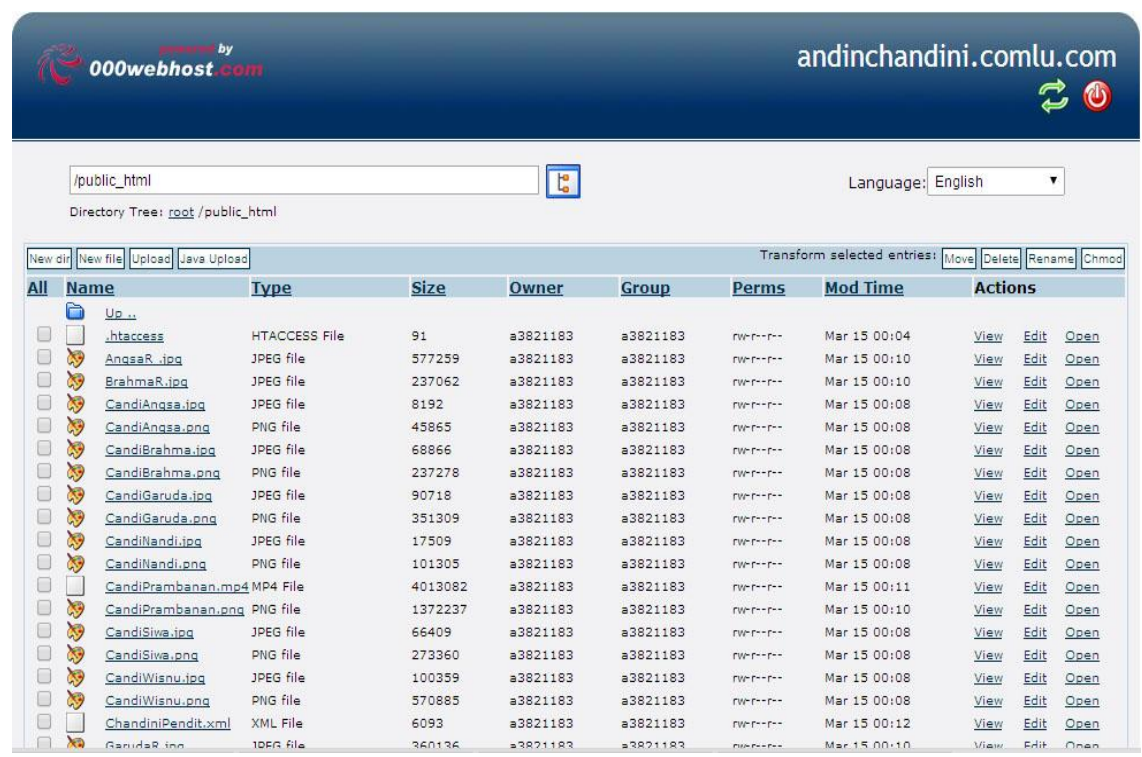

Fig 5: Storing content in webhost Database
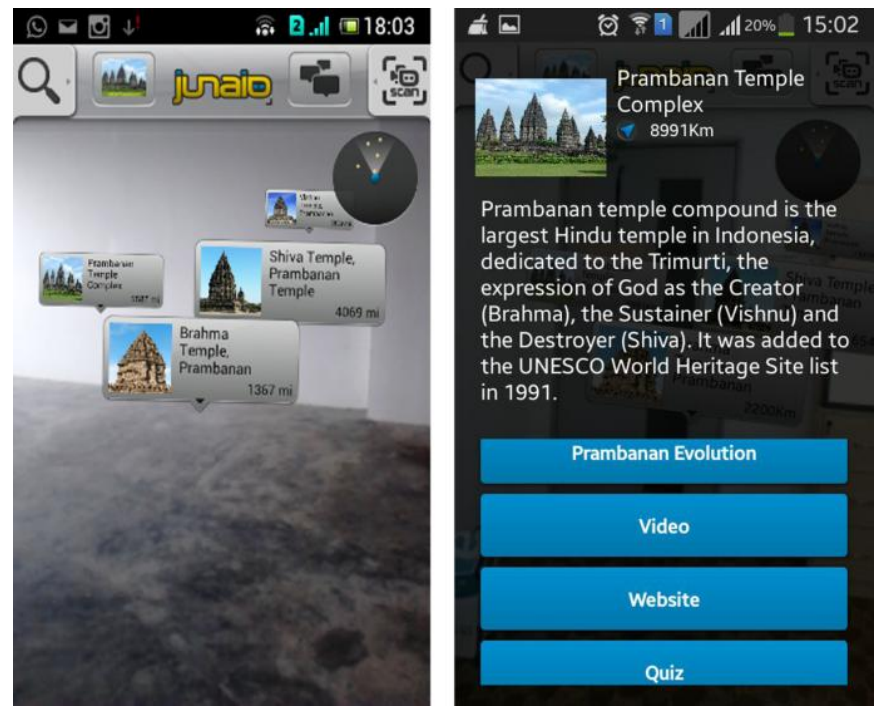

Fig 6: AR@Prambanan application
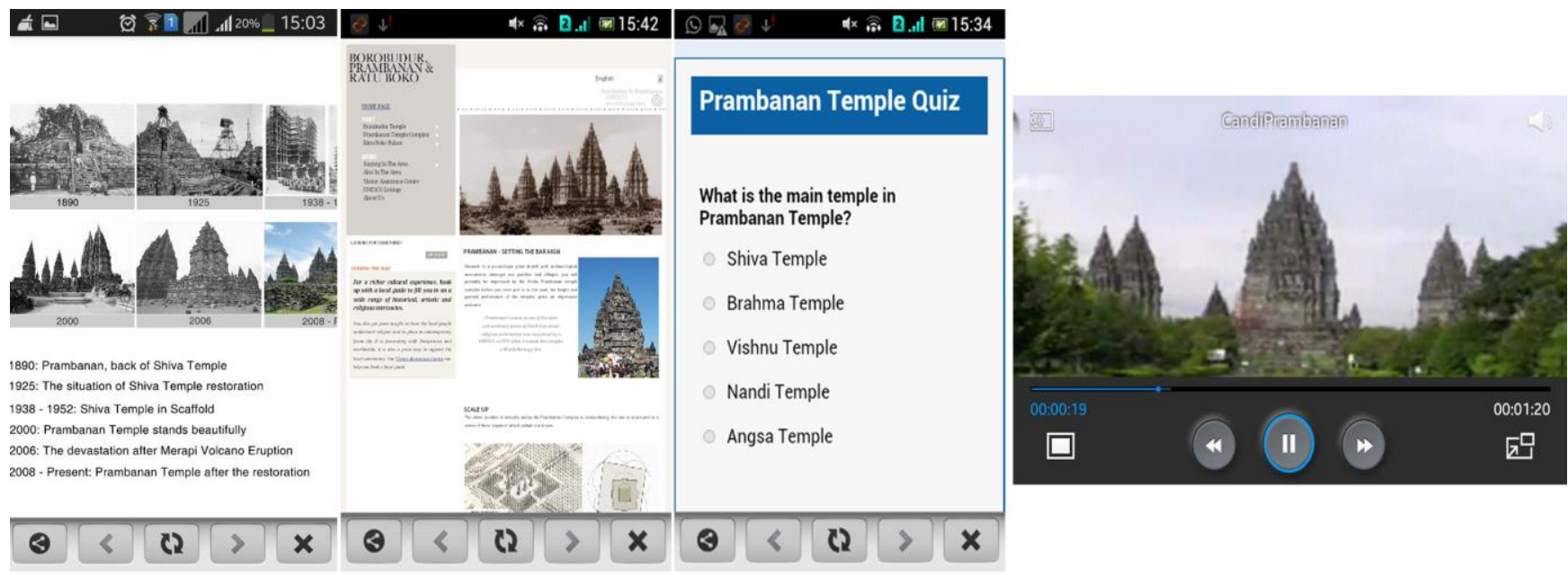

Fig 7: Option for Prambanan Temple Complex consists of Prambanan Evolution, video, website and quiz 

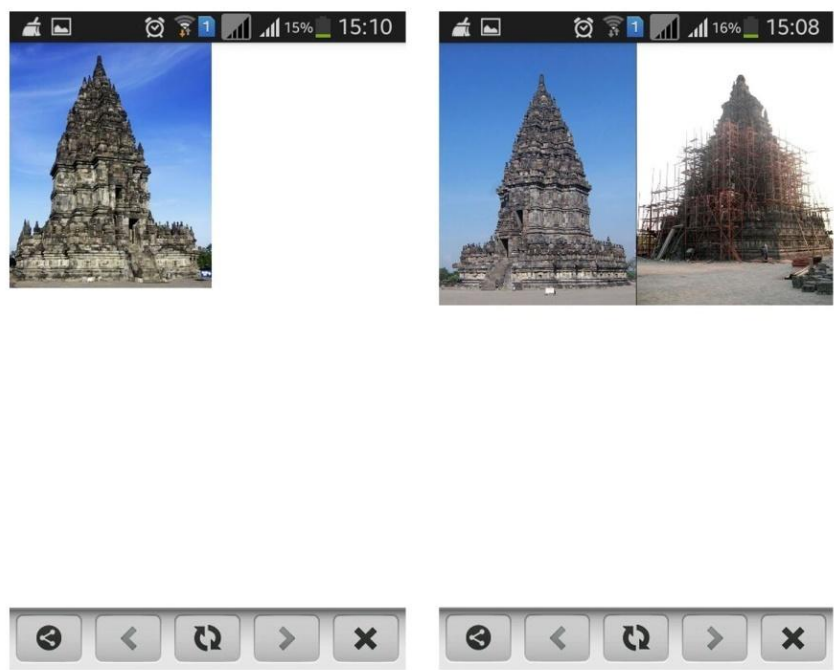

Fig 8: Media for Shiva Temple consist of image and restoration image

\section{EVALUATION}

Evaluation of study has been conducted on January, $4^{\text {th }}, 2014$ at Prambanan Temple Complex, Yogyakarta, Indonesia. The purpose of the evaluation is to seek the important features and guidelines for mobile AR for cultural heritage towards enjoyable informal learning also measure the applicability of AR@Prambanan application. The questionnaire consists of two open-ended questions and two close-ended questions which are adapted from study of website usage for museum learning by Aleck Lin, Walter Fernandez and Shirley Gregor in 2012 [5]. The questionnaire use 5-point likert scale, which are extremely not important, important, neutral, important and extremely important.

The approach of the evaluation is the visitor are offered to try the AR@Prambanan application and asked to answer the questionnaire afterwards. There are thirty respondents from both domestic visitors and international visitors with the range of age from 21 to 60 years old. The demographic profiles include gender, age and nationality of the respondents are illustrated in following tables (refer to table 2):

Table 2. Frequency of Gender

\begin{tabular}{|l|c|c|}
\hline Demographic & Criteria & Frequency \\
\hline Gender & Male & 14 \\
\hline Age & Female & 16 \\
\hline & $21-30$ & 22 \\
\hline & $31-40$ & 3 \\
\hline Nationality & Indonesian & 14 \\
\hline & Foreigner & 16 \\
\hline
\end{tabular}

The total of female and foreigner respondents are bigger than male and Indonesian respondents. In addition, the majority range of age of respondents is from 21 to 30 years old.

The first question of evaluation asks about the criteria of AR features for informal learning at cultural heritage site. The highest score is obtained by short and simple learning content with overall mean 4.4333 . The second highest score goes to the accessibility to people anywhere at anytime criteria (4.3000) followed by attractive interface criteria (4.2667) and easy to use and find way around criteria (4.2667). The criterion of opportunities to interact reaches the lowest score with 3.9667. The figure 9 illustrates the overall mean score of AR criteria for informal learning at cultural heritage site.

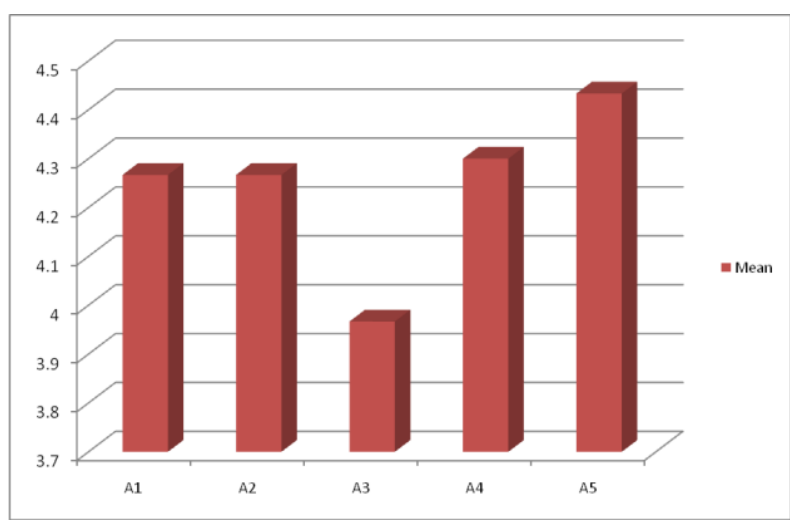

Figure 9. AR Features for Informal Learning at Cultural Heritage Site

The second question of evaluation is open-ended question asks about other AR content suggestions (3D virtual characters, hologram, etc) that visitor considers important for informal learning at cultural heritage site. The highest score is reached by $3 \mathrm{D}$ virtual character content with $16.67 \%$. Besides, other content such as, timeline, hologram, history, projection, pictures in temple, detail information, explainable photograph and also updated pictures have the same score with $3.33 \%$. 
Figure 10 illustrates the suggested AR content for informal learning at cultural heritage site.

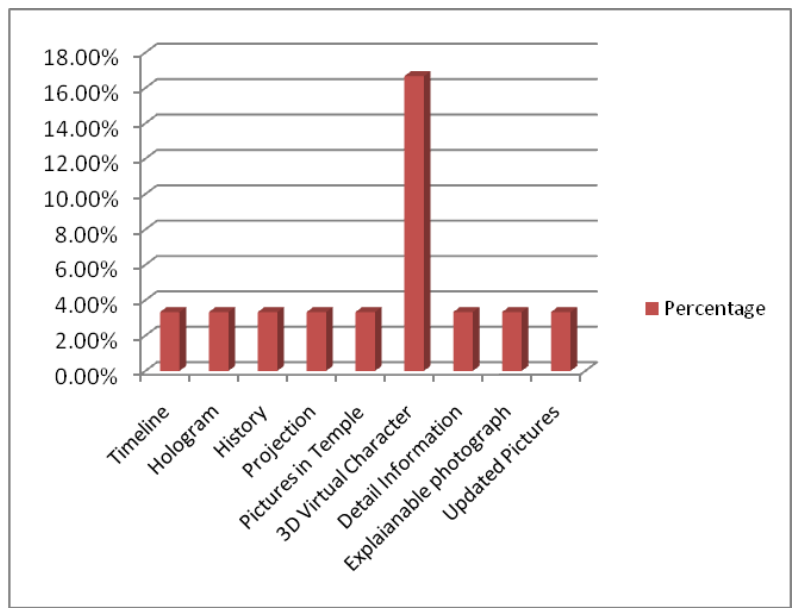

Figure 10. Suggested AR Content for Informal Learning at Cultural Heritage Site

The third question asks about guidelines for designing mobile AR for informal learning. The highest score is reached by the freedom of visitor to explore their interest with 4.3333. The second highest score goes to the use of interactive media with 4.222. The guideline of the use of narrative storytelling to present content, the feel of fun and enjoy while using the application and arouses the positive mood obtains the same score which is 4.1852. The lowest score is reached by connection to social media with score 3.8889 . Figure 11 illustrates the mean score of guidelines for designing mobile AR for informal learning.

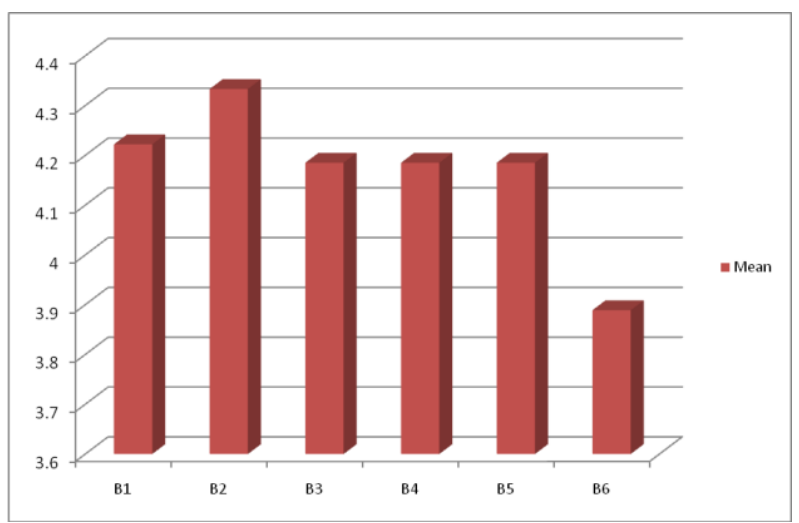

Figure 11. Guidelines for Designing Mobile AR for Informal Learning

The fourth question is an open-ended question that asks other important guidelines for designing mobile AR for informal learning. There are only a few answers for this question. The two received answers are the audio content addition and more information about the cultural heritage site with the same score $3.33 \%$.

Three from thirty respondents $(10 \%)$ mention the importance of application to be standalone application which can be used without internet connection. Such kind of application for other sites is also encouraged. The response of visitor is positive towards AR@Prambanan application. Visitor feels happy with the presence of application that can help them to obtain more knowledge and enjoy their visit at Prambanan Temple. As stated in the result, the most important criteria of AR for informal learning is short and simple learning content and the freedom of visitor to explore their interest as guideline for designing mobile AR for informal learning. It concludes that the mobile AR for informal learning should let visitor to explore their interest and provide short and simple learning content.

\section{CONCLUSION}

Enjoyable Informal learning is essential to be conducted in cultural heritage site. This paper contributes to enjoyable informal learning criteria which are adapted from the theory of enjoyment, theory of mindfulness and design of enjoyable technology. The AR@Prambanan is mobile AR application for enjoyable informal learning in cultural heritage that is developed to help visitor for conducting enjoyable informal learning in Prambanan Temple Complex, Yogyakarta, Indonesia. The evaluation of AR@Prambanan shows positive response towards the application. This supports the implementation of mobile AR for informal learning in cultural heritage site.

\section{ACKNOWLEDGEMENT}

I acknowledge the Archaeological Conservation Centre of Yogyakarta whom has helped me to conduct the field study at Prambanan Temple Complex. I also would like to say thank you to Ministry of Education Malaysia and Universiti Utara Malaysia (http://www.uum.edu.my/) for the research grant. The project has been awarded a Bronze medal at Malaysia Technology Expo 2014.

\section{REFERENCES}

[1] Azuma R. T. 1997. A Survey of Augmented Reality. In Proceedings of the PRESENCE: Teleoperators and Virtual Environments 6, 4(August), 355-385.

[2] Vlahakis, V., Karigiannis, J., Tsotros, M., Gounaris, M., Almeida, L., Stricker, D., Glue, T., Christou, I. T., Carlucci, R., Ioannidis, N. 2001. ARCHEOGUIDE : First results of an Augmented Reality, Mobile Computing System in Cultural Heritage Sites. In Proceedings of the Conference on Virtual Reality, Archaeology and Virtual Heritage (VAST), 131-140.

[3] Holden, W (2011, February 28) Press Release: Mobile Augmented Reality. Available at: http://www.juniperresearch.com/viewpressrelease.php?pr $=225$

[4] Kounavis, C. D., Kasimati, A. E., \& Zamani, E. D., "Enhancing the Tourism Experience through Mobile Augmented Reality: Challenges and Prospects Regular Paper”, International Journal of Business Management, 4 (Special Issue Mobile Digital and Economy), 2012.

[5] Lin, A. C. H., Fernandez, W. D., \& Gregor, S., "Understanding Web Enjoyment Experiences and Informal Learning: A Study in A Museum Context", Journal of Decision Support Systems, 53(4), 2012, 846858.

[6] Pendit, U. C., Zaibon, S. B. 2013. Non-Personal Digital Interpretive Media at Cultural Heritage Sites. In Proceedings of the $4^{\text {th }}$ International Conference on Computing and Informatics (ICOCI), 346-351.

[7] Seo, B., Kim, K., \& Park, J.-I. 2011. Augmented RealityBased On-Site Tour Guide : A Study in Gyeongbokgung. In R. Koch \& F. Huang (Eds.), Computer Vision ACCV 2010 Workshops, 276-285. Springer Berlin Heidelberg. 
[8] Pulli, K., Chen, W.-C., Gelfand, N., Grzeszczuk, R., Tico, M., Vedantham, R., Wang, X., Xiong, Y. 2009. Mobile Visual Computing. In 2009 International Symposium on Ubiquitous Virtual Reality, 3-6.

[9] Höllerer, T. H., \& Feiner, S. K. 2004. Mobile Augmented Reality, In K. H \& H. A (Eds.), Telegeoinformatics: Location-Based Computing Servicesmputing Services, 1-39, Taylor \& Francis Books Ltd.

[10] Linaza, M.T., Marimón, D., Carrasco P., Álvarez, R., Montesa, J., Aguilar, S. R., Diez, G. 2012. Evaluation of Mobile Augmented Reality Applications for Tourism Destinations. In M. Fuchs et al. (Eds.), Information and Communication Technologies in Tourism 201, 260-271, Vienna: Spinger.

[11] Davis, W. A. 1982. A Causal Theory of Enjoyment. Mind, New Series, Oxford University Press.

[12] Warner, R. 1980. Enjoyment. The Philosophical Review, Duke University Press.

[13] Beck, M. "The Cognitive Character of Aesthetic Enjoyment", The Journal of Aesthetic and Art Criticism $3(11 / 12), 2004,55-61$.
[14] Dishman, R. K., MOTL, R. W., Saunders, R., Felton, G., Ward, D. S., Dowda, M., Russel, R. P. "Enjoyment Mediates Effect of A School-Based Physical-Activity Intervention", Medicine and Science in Sports \& Exercise, 2005, 478-487.

[15] Walker, K. B. 2007. The Role of Interpretation in Sustainable Tourism: A Qualitative Approach to Understanding Passenger Experiences on Expedition Cruises. Doctoral Thesis. James Cook University.

[16] Moscardo, Giana. "Mindful Visitors Heritage and Tourism", Annal of Tourism Research, 23(2), 1996, 376-397.

[17] Moscardo, G. 2001. Cultural and Heritage Tourism : The Great Debates. In B. Faulkner, G. Moscardo, \& E. Laws (Eds.), Tourism in the 21st Century: Lessons from Experience, 3-16. London: Continuum.

[18] Brandtzaeg, P. B., Følstad, A., Heim, J. 2003. Enjoyment:Lessons From Karasek. In Mark A. Blythe Kees Overbeeke, Andrew F. Monk, Peter C. Wright (Eds.), Funology From Usability to Enjoyment, 55-66, Netherlands:Kluwer. 